\title{
Pengaruh Mekanisme Good Corporate Governance (GCG) dan Profitabilitas Perusahaan Terhadap Peringkat Obligasi (studi empiris pada Perusahaan Manufaktur yang terdaftar di BEI tahun 2014-2015)
}

\author{
Kunni Fauztina Sahhyla \\ e-mail: kunnisahhyla@gmail.com
}

\author{
Sulistyo \\ Rita Indah Mustikowati \\ (Program Studi Akuntansi, Fakultas Ekonomika dan Bisnis Universitas Kanjuruhan, Malang)
}

\begin{abstract}
ABSTRAK
Penelitian ini bertujuan untuk mengetahui pengaruh mekanisme good corporate governance dan profitabilitas perusahaan terhadap peringkat obligasi. Populasi yang digunakan dalam penelitian ini adalah perusahaan yang terdaftar di Bursa Efek Indonesia periode 2014-2015 dan metode penentuan sampel yang digunakan adalah purposive judgement sampling. Sampel yang diperoleh sebanyak 32 perusahaan penerbit obligasi. Teknik analisis data yang digunakan adalah analisis deskriptif, uji asumsi klasik, uji regresi linear berganda, dan pengujian hipotesis. Penelitian ini menemukan bahwa secara simultan mekanisme good corporate governance dan profitabilitas perusahaan berpengaruh terhadap peringkat obligasi. Secara parsial penelitian ini menemukan bahwa mekanisme good corporate governance yang diproksikan oleh dewan direksi (DD), komite audit (KA), ukuran perusahaan (UK), dewan direksi (DK) dan profitabilitas yang diproksikan oleh Return on Assets berpengaruh terhadap peringkat obligasi, sedangkan kepemilikan manajerial (KM), kepemilikan institusional (KI) tidak berpengaruh terhadap peringkat obligasi.

Kata Kunci: Dewan Direksi, Kepemilikan Manajerial, Kepemiikan Institusional, Komite Audit, Ukuran

Perusahaan, Dewan Komisaris, Return on Assets, Peringkat Obligasi
\end{abstract}

\begin{abstract}
This study aims to determine the effect of good corporate governance mechanisms and company profitability on bond ratings. The population used in this study is companies listed on the Indonesia Stock Exchange for the period 2014-2015 and the sample determination method used is purposive judgment sampling. Samples obtained were 32 bond issuing companies. Data analysis techniques used are descriptive analysis, classic assumption test, multiple linear regression test, and hypothesis testing. This study found that simultaneous mechanisms of good corporate governance and corporate profitability affect bond ratings. Partially, this study found that the mechanism of good corporate governance that was proxied by the board of directors (DD), audit committee (KA), company size (UK), board of directors (DK) and profitability that was proxied by Return on Assets affected the bond rating, whereas Managerial ownership (KM), institutional ownership (IC) have no effect on bond ratings..
\end{abstract}

Keynotes: board of directors, Managerial ownership, institutional ownership, audit committee (KA), company size, Return on Assets, bond ratings 
Kunni Fauztina Sahhyla, Pengaruh Mekanisme Good Corporate Governance (GCG) dan Profitabilitas Perusahaan Terhadap Peringkat Obligasi (studi empiris pada Perusahaan Manufaktur yang

terdaftar di BEI tahun 2014-2015)

\section{PENDAHULUAN}

Rating obligasi menggambarkan kemampuan untuk memenuhi kewajibannya, yaitu membayar kupon obligasi maupun mengembalikan pokok obligasi pada saat jatuh tempo. Melalui peringkat obligasi investor dapat mengukur atau memperkirakan seberapa besar risiko yang akan dihadapi dengan membeli obligasi tertentu. Sebelum diperjualbelikan di pasar modal, obligasi harus melalui proses pemberian peringkat (rating) dan dilakukan oleh suatu lembaga yaitu agen pemeringkat obligasi (Rating Agency). Agen pemeringkat adalah suatu lembaga independen yang menerbitkan peringkat serta memberikan informasi mengenai risiko kredit untuk berbagai surat hutang (bond rating atau oeringkat obligasi) maupun peringkat untuk perusahaan itu sendiri (general bond rating). (Fitrianingsih, 2015:2). Salah satu agen pemeringkat utama yang dipercaya perusahaan untuk menilai obligasinya adalah PT. Pefindo. PT. Pefindo merupakan salah satu badan perseroan terbatas swasta yang didirikan atas inisiatif OJK (Otoritas Jasa Keuangan) dan Bank Indonesia serta merupakan suatu penunjang Pasar Modal Indonesia yang bekerja secara objektif dan indpenden.

Mekanisme GCG juga dapat mengurangi risiko gagal bayar dengan cara mengurangi biaya agensi yaitu dengan memonitor kinerja manajemen dan mengurangi asimetri informasi antara perusahaan dan kreditur. Implementasi dalam penerapan Good Corporate Governance atau Tata Kelola Perusahaan dapat member keyakinan dalam pengembalian return atau investasi, khususnya bagi investor dan kreditor. Menurut Mustikasari (2010) penerapan tata kelola perusahaan yang baik dapat mencegah hazard dari manajemen sehingga memungkinkan segera dilakukan tindakan perbaikan yang pada akhirnya dapat meningkatkan kinerja perusahaan dan tingginya peringkat surat utang.

Rasio profitabilitas yang diukur dengan return on asset (ROA) mempunyai pengaruh yang positif terhadap pertumbuhan laba karena rasio ini mengukur kemampuan perusahaan dalam menghasilkan laba bersih berdasarkan tingkat asset tertentu. Semakin tinggi tingkat profitabilitas perusahaan diharapkan akan semakin rendah resiko ketidakmampuan membayar (default) dan semakin baik peringkat yang diberikan terhadap perusahaan tersebut (Rasyid dan Joice, 2013:1).

Tujuan penelitian ini adalah untuk menguji dan menjelaskan secara simultan mekanisme GCG dan Profitabilitas Perusahaan terhadap Peringkat Obligasi, serta menguji dan menjelaskan secara parsial Dewan Direksi, Kepemilikan Manajerial ,Kepemilikan Institusional, Komite Audit, Ukuran Perusahaan, Dewan Komisaris, dan Profitbilitas Perusahaan berpengaruh terhadap Peringkat Obligasi.

Berdasarkan latar belakang dan permasalahan diatas maka judul dalam penelitian ini adalah Pengaruh Mekanisme Good Corporate Governance dan Profitabilitas Perusahan Terhadap Peringkat Obligasi yang terdaftar di Bursa Efek Indonesia (BEI) Tahun 2014-2015.

\section{TINJAUAN PUSTAKA}

Bursa Efek Surabaya (2001) mengartikan obligasi sebagai surat utang jangka menengahpanjang yang dapat dipindahtangankan yang berisi janji dari pihak yang menerbitkan untuk membayar imbalan berupa bunga pada periode tertentu dan melunasi pokok utang pada waktu yang telah ditentukan kepada pihak pembeli obligasi tersebut. Obligasi merupakan surat berharga yang memberikan pendapatan tetap kepada pemiliknya selama jangka waktu berlakunya surat utang tersebut. Hal ini disebabkan pendapatan yang diterima pemilik obligasi (pokok dan bunga) tidak terpengaruh oleh perusahaan harga sekuritas utang yang bersangkutan. Peringkat obligasi merupakan indikator ketepat waktuan pembayaran pokok dan bunga utang obligasi. Selain itu, peringkat obligasi mencerminkan skala risiko dari semua obligasi yang diperdagangkan (Mustikasari, 2010).

\section{Pengaruh Mekanisme GCG dan Profitabilitas Perusahaan terhadap Peringkat Obligasi}


Kunni Fauztina Sahhyla, Pengaruh Mekanisme Good Corporate Governance (GCG) dan Profitabilitas Perusahaan Terhadap Peringkat Obligasi (studi empiris pada Perusahaan Manufaktur yang

terdaftar di BEI tahun 2014-2015)

Penelitian Ariwangsa (2012) menghasilkan bahwa mekanisme corporate governance mempunyai pengaruh positif signifikan pada peringkat obligasi walaupun untuk proksi kepemilikan institusional maupun kepemilikan manajerial tidak memiliki pengaruh pada peringkat obligasi. Penelitian yang dilakukan Rasyid dan Joice (2013) juga menunjukkan mekanisme GCG untuk proksi komite audit dan kualitas audit secara signifikan berpengaruh positif pada peringkat obligasi.

Rasio profitabilitas yang diukur dengan Return on Asset (ROA) mempunyai pengaruh yang positif terhadap pertumbuhan laba karena rasio ini mengukur kemampuan perusahaan dalam menghasilkan laba bersih berdasarkan tingkat asset tertentu. Semakin tinggi tingkat profitabilitas perusahaan diharapkan maka akan memberikan peringkat yang baik pula kepada obligasi yang diterbitkan perusahaan sehingga rasio profitabilitas dikatakan dapat mempengaruhi peringkat obligasi (Maria, 2014:8).

H1: Mekanisme GCG dan Profitabilitas Perusahaan berpengaruh terhadap Peringkat Obligasi

\section{Pengaruh Dewan Direksi terhadap Peringkat Obligasi}

Ukuran Dewan Direksi juga sebagai salah satu komponen good corporate governance yang sangat berperan penting dalam mengatasi manajemen laba. Keberadaan Dewan Direksi tersebut sebagai mekanisme pengendali internal utama untuk memonitor para manajer perusahaan (Subhan, 2011).Apabila jumlah Dewan Direksi sedikit, maka praktik manajemen laba dapat dikurangi karena komunikasi dan koordinasi pada ukuran dewan direksi yang kecil dalam aktivitas tersebut lebih efektif dibandingkan dengan ukuran direksi yang besar sehingga dapat meningkatkan pengawasan terhadap manajemen (Purwandari, 2011).

$\mathrm{H}_{2}$ : Dewan Direksi berpengaruh terhadap Peringkat Obligasi

Pengaruh Kepemilikan Manajerial terhadap Peringkat Obligasi

Berdasarkan Dali (2015:32) kepemilikan manajerial adalah pemegang saham dari pihak manajemen yang secara aktif ikut dalam pengambilan keputusan perusahaan. Kepemilikan saham manajerial dapat membantu pernyataan kepentingan antara pemegang saham dengan manajer. Semakin meningkat proporsi kepemilikan saham manajerial maka semakin baik kinerja perusahaan sehingga akan berpengaruh terhadap peringkat obligasi.

$\mathrm{H}_{3}$ : Kepemilikan Manajerial berpengaruh terhadap Peringkat Obligasi

Pengaruh Kepemilikan Institusional terhadap Peringkat Obligasi

Rahmayani (2009) menyatakan bahwa salah satu cara yang dapat digunkan untuk mengurangi konflik agensi adalah dengan mengaktifkan monitoring melalui investor-investor institusional.Adanya kepemilikan institusional maka tata kelola perusahaan yang baik dapat dilaksanakan, sehingga dapat mencegah hazard dari manajemen atau segera melakukan tindakan perbaikan manajemen yang pada akhirnya dapat meningkatkan kinerja perusahaan dan peringkat surat utangnya tinggi (Rinaningsih, 2008).

$\mathrm{H}_{4}$ : Kepemilikan Institusional berpengaruh terhadap Peringkat Obligasi

Pengaruh Komite Audit terhadap Peringkat Obligasi

Komite audit yang efektif diperlukan dalam pencapaian Good Corporate Governance. Untuk membangun komite audit yang efektif maka prinsip dan landasan yang harus dipegang oleh komite audit meliputi independensi, transparansi dan disclousure, akuntabilitas dan tanggung jawab serta sikap yang adil. Ada beberapa manfaat dari pembentukan komite audit dalam perusahaan. Pertama, dalam hal penyusunan laporan keuangan perusahaan, komite audit melaksanakan pengawasan independen atas penyusunan laporan keuangan dan pelaksanaan audit ekstern. Kedua, komite audit memberikan pengawasan independen atas proses pengelolaan resiko dan kontrol. Ketiga, komite audit melaksanakan pengawasan independen atas proses pelaksanaan yang baik dan 
Kunni Fauztina Sahhyla, Pengaruh Mekanisme Good Corporate Governance (GCG) dan Profitabilitas Perusahaan Terhadap Peringkat Obligasi (studi empiris pada Perusahaan Manufaktur yang

terdaftar di BEI tahun 2014-2015)

penting dalam mempengaruhi kualitas pelaporan keuangan yang pada akhirnya akan mempengaruhi manajemen laba (Herianto, 2013).

$\mathrm{H}_{5}$ : Komite Audit berpengaruh terhadap kinerja keuangan

Pengaruh Ukuran Perusahaan terhadap Peringkat Obligasi

Dewi (2012:12) menyatakanbahwa Ukuran perusahaan merupakan pengukur yang menunjukkan besar kecilnya perusahaan. Ukuran perusahaan dapat diukur dengan menggunakan total aset, penjualan dan ekuitas. menyatakan bahwa total hutang dan ukuran perusahaan memiliki korelasi kuat dan positif. Artinya, semakin besar ukuran suatu perusahaan semakin besar potensi atau kemampuan perusahaan dalam melunasi kewajibannya. Hal ini secara tidak langsung berpengaruh pada peringkat obligasi karena semakin besar pula kemungkinan hutang obligasi terpenuhi. Menurut Yasa (2010: 9) ukuran perusahaan yang semakin besar menunjukkan kemampuan perusahaan menguasai pasar dan kredibilitas yang lebih baik sehingga bisa meningkatkan peringkat obligasi.

H6: Ukuran Perusahaan berpengaruh terhadap Peringkat Obligasi

\section{Pengaruh Dewan Komisaris terhadap Peringkat Obligasi}

Peran dewan komisaris ini diharapkan dapat meminimalisir permasalahan yang terjadi di antara dewan direksi dengan pemegang saham. Oleh karena itu, dewan komisaris seharusnya dapat mengawasi kinerja direksi yang dihasilkan sesuai dengan kepentingan pemegang saham. Besarnya jumlah Dewan Komisaris disuatu perusahaan, pengawasan akan jauh lebih baik karena Dewan Komisaris dapat memberi masukan atau opsi kepada Direksi. Perusahaan dengan jumlah Dewan Komisaris yang besar memungkinkan Direksi untuk mengelola perusahaan dengan baik dan juga dalam pengelolaan pembiayaan surat hutang perusahaan (Jelita, 2014).

$\mathrm{H}_{7}$ : Dewan Komisaris berpengaruh terhadap Peringkat Obligasi

\section{Pengaruh Profitabilitas Perusahaan terhadap Peringkat Obligasi}

Menurut Dewi dan Yasa (2016) Apabila rasio profitabilitas dari sebuah perusahaan, maka semakin tinggi tingkat laba operasi yang dihasilkan yang kemudian digunakan untuk melunasi kewajiban bunga atau utang lainnya. Dengan demikian ini akan berpengaruh terhadap peringkat obligasi.. Menurut Yuliana et al. (2011) semakin tinggi profitabilitas artinya perusahaan semakin efisien untuk memperoleh laba dengan perputaran total asset yang dimilikinya dan semakin baik kemampuan perusahaan dalam membayar bunga periodic dan melunasi pokok hutang obligasi sehingga dapat meningkatkan peringkat obligasi perusahaan.

$\mathrm{H}_{8}$ : Profitabilitas berpengaruh terhadap Peringkat Obligasi 
Kunni Fauztina Sahhyla, Pengaruh Mekanisme Good Corporate Governance (GCG) dan Profitabilitas Perusahaan Terhadap Peringkat Obligasi (studi empiris pada Perusahaan Manufaktur yang

terdaftar di BEI tahun 2014-2015)

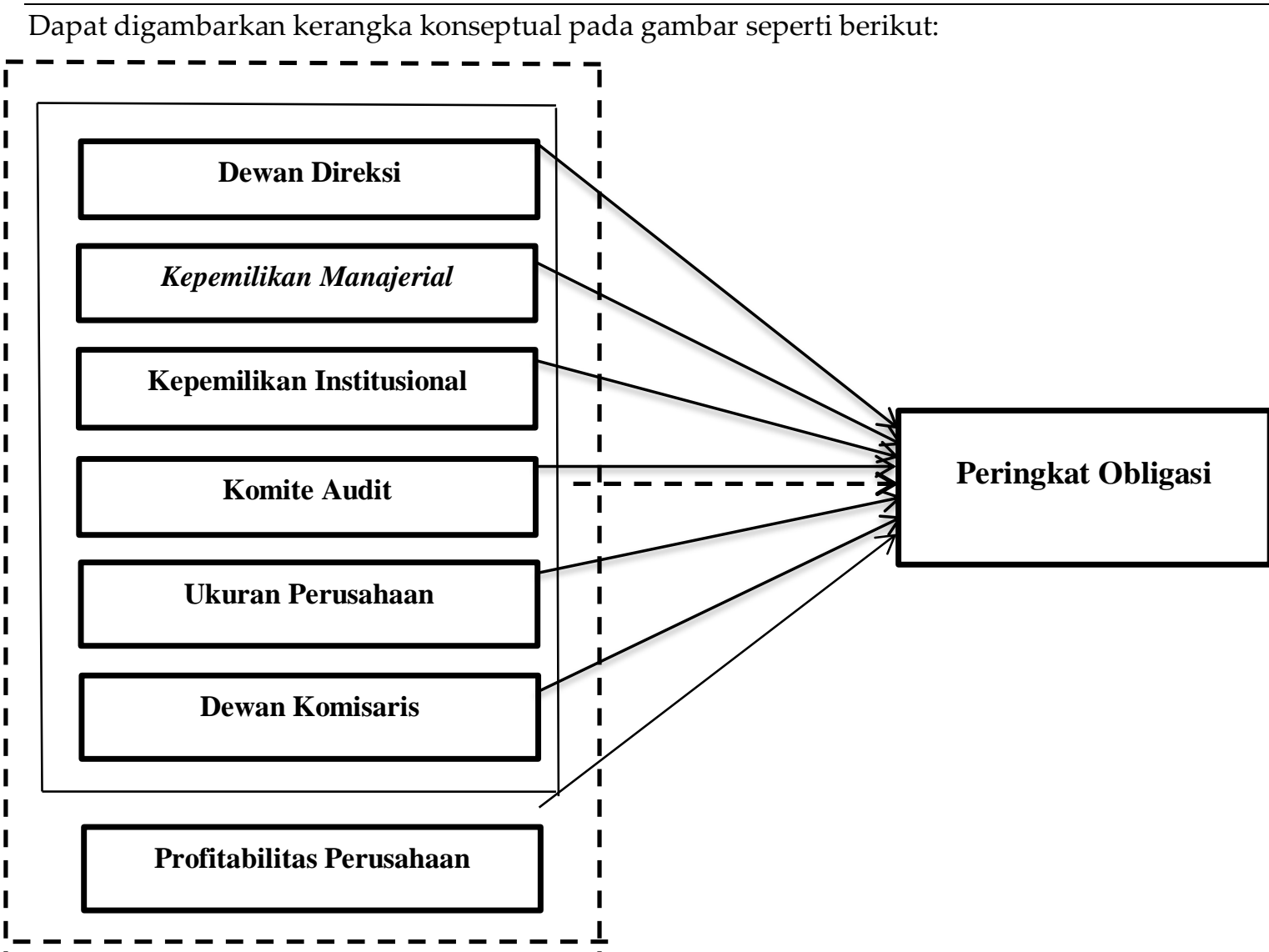

Gambar 2.1

Kerangka Konseptual

\section{METODE}

jenis penelitian yang digunakan adalah explanatory research, yaitu menjelaskan hubungan kausal antara variabel-variabel penelitian melalui pengujian. Penelitian ini menggunakan metode penelitian kuantitatif. Metode penelitian kuantitatif dapat diartikan sebagai metode penelitian yang berlandaskan pada filsafat positivisme, digunakan untuk meneliti pada populasi atau sampel tertentu, pengumpulan data menggunakan instrument penelitian, analisis data bersifat kuantitatif atau statistik, dengan tujuan untuk menguji hipotesis yang telah ditetapkan(Sugiyono, 2012:88). Berupa laporan tahunan perusahaan perbankan periode 2014-2015, yang diperoleh dari situs BEI yang di akses melalui www.idx.co.id serta studi pustaka, jurnal dan lain-lain.

Teknik pengambilan sampel dalam penelitian ini menggunakan purposive sampling yang mengacu pada Ferdinand (2011) sampel dipilih dengan menggunakan pertimbangan tertentu yang disesuaikan dengan tujuan atau masalah penelitian yang dikembangakan dengan menentukan kriteria-kriteria dalam penyeleksian sampel. Kriteria-kriteria sampel yang digunakan dalam penelitian ini sebagai berikut:

1. Perusahaan di Indonesia yang termasuk dalam golongan perusahaan manufaktur sesuai dengan kategori yang dikembangkan oleh Bursa Efek Indonesia yang tercantum dalam IDX selama tahun 2014-2015

2. Perusahaan manufaktur tidak keluar (delisting) dari BEI selama tahun 2014-2015

3. Perusahaan menerbitkan data laporan keuangan tahunan yang lengkap selama periode pengamatan 2014-2015 
Kunni Fauztina Sahhyla, Pengaruh Mekanisme Good Corporate Governance (GCG) dan Profitabilitas Perusahaan Terhadap Peringkat Obligasi (studi empiris pada Perusahaan Manufaktur yang

terdaftar di BEI tahun 2014-2015)

4. Perusahaan yang tidak mengalami rugi selama periode pengamatan 2014-2015

5. Perusahaan manufaktur yang menerbitkan peringkat obligasinya selama periode 20142015

Tabel 3.1

Seleksi Sampel Penelitian

\begin{tabular}{|c|l|r|}
\hline No & \multicolumn{1}{|c|}{ Kriteria Sampel } & \multicolumn{1}{|c|}{ Jumlah } \\
\hline 1. & $\begin{array}{l}\text { Perusahaan Manufaktur yang terdaftar di BEI periode } \\
2014-2015\end{array}$ & 143 \\
\hline 2. & $\begin{array}{l}\text { Perusahaan Manufaktur yang tidak menerbitkan } \\
\text { peringkat obligasi }\end{array}$ & $(123)$ \\
\hline 3. & Perusahaan manufaktur yang mengalami rugi & 16 \\
\hline & Jumlah sampel & \\
\hline
\end{tabular}

Sumber: Data diolah peneliti tahun 2017

Devinisi operasional dan pengukuran variabel

Variabel dependen sering disebut variabel output kriteria, konsekuen. Dalam bahasa Indonesia sering disebut sebagai variabel terikat. Variabel terikat merupakan variabel yang dipengaruhi atau yang menjadi akibat, karena adanya variabel bebas (Sugiyono,2012). Variabel dependen yang digunakan dalam penelitian ini adalah peringkat obligasi yang di keluarkan oleh PT. Pefindo (Pemeringkat Efek Indonesia).

Tabel 3.4 Konversi Peringkat Obligasi

Peringkat Obligasi Kategori Nilai

\begin{tabular}{|l|l|c|}
\hline \multicolumn{1}{|c|}{ Peringkat Obligasi } & Kategori & Nilai \\
\hline idAAA & Investment Grade & 8 \\
\hline idAA+ & Investment Grade & 7 \\
\hline idAA & Investment Grade & 7 \\
\hline idAA- & Investment Grade & 7 \\
\hline idA+ & Investment Grade & 6 \\
\hline idA & Investment Grade & 6 \\
\hline idA- & Investment Grade & 6 \\
\hline idBBB+ & Investment Grade & 5 \\
\hline idBBB & Investment Grade & 5 \\
\hline idBBB- & Investment Grade & 5 \\
\hline idBB+ & Speculative Grade & 4 \\
\hline idBB & Speculative Grade & 4 \\
\hline idBB- & Speculative Grade & 4 \\
\hline idB+ & Speculative Grade & 3 \\
\hline idB & Speculative Grade & 3 \\
\hline idB- & Speculative Grade & 3 \\
\hline idCCC+ & Speculative Grade & 2 \\
\hline idCCC- & Speculative Grade & 2 \\
\hline idD/idSD & Speculative Grade & 1 \\
\hline
\end{tabular}

Sumber : www.pefindo.com 
Kunni Fauztina Sahhyla, Pengaruh Mekanisme Good Corporate Governance (GCG) dan Profitabilitas Perusahaan Terhadap Peringkat Obligasi (studi empiris pada Perusahaan Manufaktur yang

terdaftar di BEI tahun 2014-2015)

Variabel independen adalah variabel yang menjelaskan atau mempengaruhi variabel yang lain. Penelitian ini menggunakan variabel mekanisme good corporate governance dan profitabilitas perusahaan sebagai variabel independen. Berikut ini merupakan penjelasan dari variabel independen:

Ukuran Dewan Direksi adalah jumlah anggota dewan direksi yang ada dalam perusahaan. Keadaan dewan direksi tersebut bertugas sebagai mekanisme pengendali internal untuk memonitor para manajer perusahaan. Maka ukuran dewan direksi diukur dengan (Fitrianingsih, 2015):

Ukuran Dewan Direksi = Anggota Dewan Direksi

Kepemilikan manajerial (manajerial ownership) adalah pemegang saham dari pihak manajemen yang secara aktif ikut dalam pengambilan keputusan. Kepemilikan manajerial merupakan persentase kepnemilikan saham oleh pihak manajemen (direktor dan komisaris) (Abdillah, 2016:41).

$$
\mathrm{KM}=\frac{\text { Jumah lembar saham yang dimiliki manajemen }}{\text { Total lembar saham yang beredar }} \times 100 \%
$$

Kepemilikan institusional (institusional ownership) merupakan presentase kepemilikan saham perusahaan yang dimiliki investor institusional seperti pemerintah, perusahaan investasi, bank, perusahaan asuransi maupun kepemilikan lembaga dan perusahaan lain. Kepemilikan institusional diukur dengan persentase kepemilikan institusi dalam struktur saham perusahaan (Abdillah, 2016:41).

$$
\mathrm{KI}=\frac{\text { Jumlah lembar saham yang dimiliki institusi }}{\text { Total lembar saham yang beredar }} \times 100 \%
$$

Komite audit dipilih oleh dewan komisaris untuk mengawasi sistem pengendalian akuntansi perusahaan. Keberadaan komite audit yang efektif mampu membuat kinerja perusahaan berjalan lebih baik. Komite audit dihitung dari jumlah anggota komite audit yang dimiliki (Abdillah, 2016:40).

$$
\text { Komite Audit }=\Sigma \text { Anggota Komite Audit }
$$

Ukuran dewan komisaris merupakan jumlah anggota dewan komisaris dalam suatu perusahaan, yaitu komisaris utama, komisaris utama dan komisaris independen. Variable ukuran dewan komisaris dihitung dari jumlah nominal anggota dewan komisaris yang tercantum dalam laporan keuangan tahunan. Variable ukuran dewan komisaris dilambangkan dengan DKOM (Fitrianingsih, 2015):

Ukuran Dewan Komisaris $=\sum$ Anggota Dewan Komisaris

\section{Teknik Analisis Data}

\section{Pengujian asusmsi klasik}

\section{Uji Normalitas}

Uji normalitas bertujuan untuk mengetahui apakah dalam model regresi variabel penganggu memiliki distribusi normal. Serpeti diketahui bahwa uji $\mathrm{t}$ dan $\mathrm{F}$ mengasumsikan bahwa nilai residual mengikuti distribusi normal. Jika asumsi ini dilanggar maka uji statistik menjadi tidak valid untuk jumlah sampel kecil. , uji normalitas juga dapat diuji dengan statistik non-parametrik Kolmogorov Smirnov (K-S) dengan menggunakan taraf signifikansi 5\%. Jika, signifikansi (dapat dilihat pada Asymp. Sig. (2-tiled) pada output SPSS) dari nilai Kolmogorov Smirnov $>5 \%$, data yang digunakan berdistribusi normal (Ghozali, 2013).

Uji Multikolinieritas 
Kunni Fauztina Sahhyla, Pengaruh Mekanisme Good Corporate Governance (GCG) dan Profitabilitas Perusahaan Terhadap Peringkat Obligasi (studi empiris pada Perusahaan Manufaktur yang

terdaftar di BEI tahun 2014-2015)

Uji multikolinearitas merupakan syarat yang digunakan dalam analisis regresi berganda yang digunakan untuk mengkaji ada korelasi atau tidak ada korelasi antar variabel independen. Model regresi yang baik seharusnya tidak terjadi korelasi antar variabel independen (Umar, 2011). Multikolinearitas dalam model regresi dapat dilihat dari nilai variance inflation factor (VIF). Apabila nilai VIF lebih besar dari satu (VIF $>10)$ menunjukkan adanya gejala multikolinearitas. Sedangkan, nilai VIF yang mendekati satu menunjukkan tidak adanya gejala multikolinearitas (Ghozali, 2013).

Uji Autokorelasi

Uji autokorelasi bertujuan untuk mengetahui hubungan yang kuat baik positif maupun negatif atau tidak ada hubungan antar data yang ada pada variabel-variabel penelitian dalam model regresi linier. Pengujian adanya autokolerasi dapat dilakukan menggunakan uji DurbinWatson Test. Tidak terjadi autokorelasi, jika nilai DW berada diantara 1,55 -2,46 atau 1,55 $\leq \mathrm{DW}$ $\leq 2,46$ (Ghozali, 2013).

\section{Uji Heteroskedastisitas}

Uji heteroskedastisitas bertujuan untuk menguji dalam model regresi terjadi kesaman atau ketidaksamaan varian dari residual satu pengamatan kepengamatan yang lain. Jika variansi dari residual satu pengamatan ke pengamatan lain tetap maka disebut homoskedastisitas dan jika berbeda disebut heteroskedasitas. Jika plot menyebar secara terpencar dan tidak membentuk pola tertentu maka dapat disimpulkan bahwa tidak terjadi masalah heteroskedastisitas (Ghozali, 2013).

\section{Analisis Regresi Linier Berganda}

Analisis regresi linier berganda digunakan untuk mengetahui arah hubungan antara variabel independen dengan variabel dependen, apakah masing-masing variabel independen berhubungan positif atau negatif danuntuk memprediksi nilai dari variabel dependen apabila nilai variabel independen mengalami kenaikan atau penurunan. (Sugiyono, 2012). Persamaan regresi linier berganda dapat dinyatakan sebagai berikut:

$$
Y=\beta_{0}+\beta_{1} X_{1}+\beta_{2} X_{2}+\beta_{3} X_{3}+\beta_{4} X_{4}+\beta_{5} X_{5}+\beta_{6} X_{6}+\beta_{7} X_{7}+\varepsilon
$$

$\mathrm{Y}=$ Variabel peringkat obligasi dengan delapan kategori

Keterangan :

$\beta_{0}=$ Konstanta

$\beta_{1}=$ Ukuran Dewan Direksi

$\beta_{2}=$ Kepemilikan Manajerial

$\beta_{3}=$ Kepemilikan Konstitusional

$\beta_{4}=$ Ukuran komite Audit

$\beta_{5}=$ Ukuran Perusahaan

$\beta_{6}=$ Ukuran Dewan Komisaris

$\beta_{7}=$ Profitabilitas Perusahaan

$\varepsilon \quad=$ Standard Error

(Sumber : Pengembangan dari berbagai sumber)

\section{Koefisien Determinasi Ganda $\left(\mathbf{R}^{2}\right)$}

Koefisien Determinasi (R2) digunakan untuk mengetahui seberapa jauh kemampuan suatu model penelitian dalam menjelaskan variasi variabel dependen yang ada. Dengan 
Kunni Fauztina Sahhyla, Pengaruh Mekanisme Good Corporate Governance (GCG) dan Profitabilitas Perusahaan Terhadap Peringkat Obligasi (studi empiris pada Perusahaan Manufaktur yang

terdaftar di BEI tahun 2014-2015)

demikian akan diketahui seberapa besar variabel dependen dapat diterangkan oleh variabel independen yang ada. Nilai yang medekati angka 1 berarti variabel independen hampir atau mampu memberikan informasi yang dibutuhkan untuk memprediksi variasi dependen (Ghozali, 2013).

4. Pengujian Hipotesis

1. Uji Parsial (Uji-F)

Uji F dilakukan untuk mengatahui apakah variabel dependen secara bersama-sama dipengaruhi oleh variabel independen. Pengujian dapat dilakukan dengan melihat tingkat signifikansi F. Menurut Ghozali (2013) hipotesis dapat diterima dan ditolak dengan melihat keriteria sebagai berikut:

a. Jika nilai signifikansi lebih besar dari 5\% maka hipotesis ditolak

b. Jika nilai signifikansi lebih kecil dari $5 \%$ maka hipotesis diterima

2. Uji Parsial (Uji-T)

Uji ini dilakukan untuk mengetahui seberapa jauh variabel independen secara individu dalam menerangkan variabel dependen. Uji statistik $\mathrm{t}$ digunakan untuk mengetahui apakah ada perbedaan yang terjadi antara variabel-variabel uji terhadap kelompok uji. Menurut Ghozali (2013) hipotesis dapat diterima dan ditolak dengan melihat keriteria sebagai berikut:

a. Jika nilai signifikansi lebih besar dari 0,05 maka hipotesis ditolak

b. Jika nilai signifikansi lebih kecil dari 0,05 maka hipotesis diterima.

\section{HASIL DAN PEMBAHASAN}

\section{Hasil Analisis Deskriptif}

Peringkat Obligasi

Rata-rata Peringkat Obligasi dari tahun 2014 ke tahun 2015 mengalami peningkatan walaupun rentangnya tidak terlalu tinggi dimana untuk tahun 2014 rata-rata PO sebesar 6,1875\% dan tahun 2015 6,5625\%. Artinya rata-rata perusahaan Manufaktur di Indonesia masih belum begitu efektif dalam memenuhi kewajibannya membayar obligasi secara tepat waktu.Kemudian nilai tertinggi PO untuk tahun 2014 adalah ASII (Astra Internasional Tbk) dan MLBI (Multi Bintang Indonesia Tbk) yaitu sebesar 8\%. Sedangkan tahun 2015 adalah ASII (Astra Internasional Tbk), AUTO (Astra Auto Part Tbk), BTON (Beton Jaya Manunggal Tbk), MLBI (Multi Bintang Indonesia Tbk), dan SRSN (Indo Acitama Tbk) yaitu sebesar 8\%. Artinya obligasi layak untuk diperdagangkan karena resiko gagal bayar yang relative kecil. Selanjutnya nilai terendah dari PO untuk tahun 2014 adalah AUTO (Astra Auto Part Tbk), GJTL (Gajah Tunggal Tbk), INAF (Indofarma Tbk) yaitu sebesar 4\%. Sedangkan tahun 2015 adalah GJTL (Gajah Tunggal Tbk) dan INAF (Indofarma Tbk) yaitu sebesar $4 \%$. Artinya resiko gagal bayar obligasi yang cukup besar dan dihindari oleh investor. Dewan Direksi

Rata-rata jumlah Dewan Direksi untuk tahun 2014 sebesar 4,625\% dan tahun 2015 sebesar 4,875\%. Kemudian nilai tertinggi dari jumlah Dewan Direksi diperoleh oleh GJTL (Gajah Tunggal Tbk) untuk tahun 2014 dan 2015 sebesar 10\%. Artinya semakin besar jumlah DD maka semakin baik untuk meniningkatkan tujuan perusahaan untuk menghasilkan laba, jadi semakin baik untuk meningkatkan peringkat obligasi. Selanjutnya nilai terendah dari jumlah Dewan Direksi untuk tahun 2014 yaitu BTON (Beton Jaya Manunggal Tbk), INAF (Indofarma Tbk), JPFA (Japfa Camfeed Indonesia Tbk) dan MLBI (Multi Bintang Indonesia Tbk) sebesar 2\%. Sedangkan tahun 2015 yaitu BTON (Beton Jaya Manunggal Tbk) dan INAF (Indofarma Tbk) sebesar 2\%. Artinya apabila jumlah DD sedikit, mengindikasikan bahwa semakin rendah upaya untuk meningkatkan peringkat obligasi.

Kepemilikan Manajerial 
Kunni Fauztina Sahhyla, Pengaruh Mekanisme Good Corporate Governance (GCG) dan Profitabilitas Perusahaan Terhadap Peringkat Obligasi (studi empiris pada Perusahaan Manufaktur yang

terdaftar di BEI tahun 2014-2015)

Rata-rata jumlah Kepemilikan Manajerial untuk tahun 2014 sebesar 0,3244\% dan untuk tahun 2015 sebesar 0,3251\%. Kemudian nilai tertinggi dari jumlah Kepemilikan Manajerial adalah MYOR (Mayora Indah Tbk), untuk tahun 2014 yaitu sebesar 0,6639\% dan untuk tahun 2015 yaitu sebesar $0,6693 \%$. Semakin tinggi KM maka semakin baik kinerja manajer dalam mengelola perusahaan serta meniningkatkan tujuan perusahaan untuk menghasilkan laba. Selanjutnya nilai terendah dari jumlah Kepemilikan Manajerial untuk tahun 2014-2015 adalah KAEF (Kimia Farma Tbk) yaitu sebesar 0,0997\%. Artinya apabila KM rendah, mengindikasikan bahwa semakin rendah kepemilikan saham perusahaan yang dimiliki oleh pihak manajemen.

Kepemilikan Institusional

Rata-rata jumlah Kepemilikan Institusional untuk tahun 2014 sebesar 0,6772\% dan untuk tahun 2015 sebesar 0,6748\%. Kemudian nilai tertinggi dari jumlah Kepemilikan Institusional untuk tahun 2014-2015adalah KAEF (Kimia Farma Tbk) yaitu sebesar 0,9003\%. Artinya semakin tinggi KI maka semakin baik dalam tata kelola perusahaan dan akan meningkatkan peringkat surat hutangnya. Selanjutnya nilai terendah dari jumlah Kepemilikan Manajerial untuk tahun 2014-2015 adalah MYOR (Mayora Indah Tbk) yaitu sebesar 0,3307\%. Artinya apabila KI rendah, mengindikasikan bahwa semakin rendah kinerja perusahaan dan semakin rendah juga peringkat surat hutangnya.

\section{Komite Audit}

Rata-rata jumlah Komite Audit untuk tahun 2014 sebesar 2,0625\% dan untuk tahun 2015 sebesar 2\%. Kemudian nilai tertinggi dari jumlah Kepemilikan Institusional untuk tahun 2014 adalah MYOR (Mayora Indah Tbk) yaitu sebesar 3\% dan untuk tahun 2015 semua memiliki jumlah Komite Audit yang sama yaitu sebesar $2 \%$. Artinya semakin banyak jumlah KA maka semakin baik kinerja keuangan perusahaan. Selanjutnya semua memiliki nilai terendah yang sama dari jumlah Komite Audit untuk tahun 2014-2015 yaitu sebesar 2\%. Artinya apabila jumlah KA sedikit, mengidikasikan bahwa semakin rendah kinerja keuangan perusahaan.

\section{Ukuran Perusahaan}

Rata-rata jumlah Ukuran Perusahaan untuk tahun 2014 sebesar 29,17314\% dan untuk tahun 2015 sebesar 29,42192\%. Kemudian nilai tertinggi dari jumlah Ukuran Perusahaan adalah ASII (Astra Internasional Tbk) yaitu untuk tahun 2014 sebesar 33,09497\% dan untuk tahun 2015 sebesar $33,13405 \%$. Artinya semakin besar UP semakin besar potensi atau kemampuan perusahaan dalam melunasi kewajibannya melunasi hutang obligasi, maka semakin meningkat peringkat obligasinya. Selanjutnya nilai terendah dari jumlah Ukuran Perusahaan adalah BTON (Beton Jaya Manunggal Tbk) yaitu untuk tahun 2014 sebesar 25,55139\% dan untuk tahun 2015 sebesar 25,93339\%. Artinya semakin rendah UP, mengindikasikan bahwa semakin kecil potensi untuk melunasi kewajibannya. Dewan Komisaris

Rata-rata jumlah Dewan Komisaris untuk tahun 2014 sebesar 2,6875\% dan untuk tahun 2015 sebesar 2,5625\%. Kemudian nilai tertinggi dari jumlah Dewan Komisaris untuk tahun 2014-2015 adalah ASII (Astra Internasional Tbk) yaitu sebesar 6\%. Artinya semakin besar jumlah DK memungkinkan untuk mengelola perusahaan dengan baik dan juga dalam pengelolan pembiayaan surat hutang perusahaan. Selanjutnya nilai terendah dari jumlah Dewan Komisaris untuk tahun 2014-2015 adalah BTON (Beton Jaya Manunggal Tbk), INAF (Indofarma Tbk), JPFA (Japfa Comfeed Indonesia Tbk), ROTI (Nippon Indosari Corporindo Tbk) dan SMSM (Selamat Sempurna Tbk) yaitu sebesar $1 \%$. Artinya apabila jumlah DK sedikit, mengindikasikan bahwa semakin rendah pengawasan yang dimiliki perusahaan dalam melihat kinerja para direksi.

Profitabilitas Perusahaan

Rata-rata jumlah Profitabilitas Perusahaan untuk tahun 2014 sebesar 0,094969\% dan untuk tahun 2015 sebesar 0,139905\%. Kemudian nilai tertinggi dari jumlah Profitabilitas Perusahaan untuk 
Kunni Fauztina Sahhyla, Pengaruh Mekanisme Good Corporate Governance (GCG) dan Profitabilitas Perusahaan Terhadap Peringkat Obligasi (studi empiris pada Perusahaan Manufaktur yang

terdaftar di BEI tahun 2014-2015)

tahun 2014 adalah MLBI (Multi Bintang Indonesia Tbk) yaitu sebesar 0,356282\% dan untuk tahun 2015 adalah MYOR (Mayora Indah Tbk) sebesar 1,102235\%. Artinya semakin tinggi PP maka semakin efisien untuk memperoleh laba dan semakin baik dalam membayar hutang obligasi. Selanjutnya nilai terendah dari jumlah Profitabilitas Perusahaan adalah INAF (Indofarma Tbk) yaitu untuk tahun 2014 sebesar 0,011525\% dan untuk tahun 2015 sebesar 0,004281\%. Artinya semakin rendah PP, mengindikasikan semakin kecil pula tingkat keuntungan yang dicapai suatu perusahaan.

2. Hasil Uji Asumsi Klasik

Hasil Uji Asmsi Klasik Normalitas

Hasil uji asumsi klasik normalitas dilakukan uji statistik Kolmogorov-Smirnov Test. Disajikan pada lampiran 2. Nilai signifikan kolmogorof-smirnov dengan melihat Asmp Sig, suatu data dinyatakan berdistribusi normal jika nilai asymp sig (2-tailed) hasil pengujian Kolmogorov-smirnov lebih besar dari 0.05 atau 5\%. Nilai asymp sig sebesar 0.375 melebihi 0.05 (5\%). Ini berarti bahwa data variabel penggangu memiliki distribusi normal.

Hasil Uji Asumsi Klasik Multikolinieritas

Hasil uji asumsi klasik multikolinieritas dengan VIF (Variance Inflation Factor) disajikan dan diringkas pada tabel 4.9 berikut:

Tabel 4.9

Hasil Uji Asumsi Klasik Multikolinieritas

\begin{tabular}{|c|c|c|c|}
\hline Variabel & $\begin{array}{c}\text { Nilai } \\
\text { Tolerance }\end{array}$ & Nilai VIF & Simpulan \\
\hline DD & .312 & 3.201 & Tidak terjadi multikolinieritas \\
\hline KM & .168 & 5.367 & Tidak terjadi multikolinieritas \\
\hline KI & .473 & 2.116 & Tidak terjadi multikolinieritas \\
\hline KA & .222 & 4.515 & Tidak terjadi multikolinieritas \\
\hline UP & .113 & 8.881 & Tidak terjadi multikolinieritas \\
\hline DK & .418 & 2.392 & Tidak terjadi multikolinieritas \\
\hline PP & .774 & 4.515 & Tidak terjadi multikolinieritas \\
\hline
\end{tabular}

Sumber: Hasil pengolahan data tahun 2017

Hasil Uji Asumsi Klasik Autokorelasi

Hasil uji asumsi klasik autokorelasi menggunakan pendekatan Durbin Watson. Hasilnya disajikan pada Lampiran 2. Hasil uji autokorelasi menggunakan pendekatan Durbin Watson nampak bahwa nilainya sebesar 2.107 terletak di antara 1,788-2,212. Dengan demikian tidak terjadi autokorelasi.

Hasil Uji Asumsi Klasik Heteroskedastisitas

Hasil uji asumsi klasik heteroskedastisitas dengan pendekatan Scatter Plot disajikan pada Lampiran 2., dimana sebaran data tidak membentuk pola tertentu dan titik-titik menyebar di atas dan dibawah angka 0 pada sumbu Y. Pada pola gambar Scatterplot di atas terlihat bahwa titik-titik menyebar secara acak, baik di bagian atas angka 0 atau di bagian bawah angka 0 dari sumbu vertikal atau sumbu Y, demikian maka tidak terjadi heteroskedastisitas dalam model regresi ini.

\section{Hasil Analisis Regresi Linier Berganda}

Hasil analisi regresi linier berganda disajikan pada lampiran 2. Dari lampiran tersebut dapat dibuat persamaan regresi sebagai berikut:

$$
Y=\beta_{0}+\beta_{1} X_{1}+\beta_{2} X_{2}+\beta_{3} X_{3}+\beta_{4} X_{4}+\beta_{5} X_{5}+\beta_{6} X_{6}+\beta_{7} X_{7}+\varepsilon
$$


Kunni Fauztina Sahhyla, Pengaruh Mekanisme Good Corporate Governance (GCG) dan Profitabilitas Perusahaan Terhadap Peringkat Obligasi (studi empiris pada Perusahaan Manufaktur yang

terdaftar di BEI tahun 2014-2015)

$\mathrm{PO}=2.556-0.726 \mathrm{DD}-0.481 \mathrm{KM}+0.390 \mathrm{KI}+0.549 \mathrm{KA}+1.567 \mathrm{UP}-0.566 \mathrm{DK}+0.365 \mathrm{PP}+2.032$

Tabel 4.10

Ringkasan Hasil Analisis Regresi

\begin{tabular}{|c|c|c|c|}
\hline Variabel & Koefisien Regresi & Nilai Signifikansi & Kesimpulan \\
\hline Variabel X1 (DD) & -0.725 & 0.006 & Berpengaruh negatif \\
\hline Variabel X2 (KM) & -0.481 & 0.135 & Tidak Berpengaruh \\
\hline Variabel X3 (KI) & 0.390 & 0.183 & Tidak berpengaruh \\
\hline Variabel X4 (KA) & 0.549 & 0.010 & Berpengaruh Positif \\
\hline Variabel X5 (UP) & 1.567 & 0.001 & Berpengaruh Positif \\
\hline Variabel X6 (DK) & -0.566 & 0.012 & Berpengaruh Negatif \\
\hline Variabel X7 (PP) & 0.390 & 0.025 & Berpengaruh Positif \\
\hline
\end{tabular}

Sumber: data sekunder diolah peneliti tahun 2017

Berdasarkan pada persamaan tabel 4.10 dapat dijelaskan sebagai berikut:

1. Koefisien regresi variabel DD bertanda negative -0.725 . Hal ini mengindikasikan bahwa variabel DD berhubungan negatif dengan Peringkat Obligasi. Jika variabel DD ditingkatkan 1 persen, maka peringkat obligasi turun -0.725 persen.

2. Koefisien regresi variabel $\mathrm{KM}$ bertanda negatif -0.481 . Hal ini mengindikasikan bahwa variabel KM berhubungan negatif dengan Peringkat Obligasi. Jika variabel KM ditingkatkan 1 persen, maka Peringkat Obligasi turun -0.481 persen.

3. Koefisien regresi variabel KI bertanda positif 0.390 . Hal ini mengindikasikan bahwa variabel KI berhubungan positif dengan Peringkat Obligasi. Jika variabel KI ditingkatkan 1 persen, maka Peringkat Obligasi turun 0.390 persen.

4. Koefisien regresi variabel KA bertanda positif 0.549 . Hal ini mengindikasikan bahwa variabel KA berhubungan positif dengan Peringkat Obligasi. Jika variabel KA ditingkatkan 1 persen, maka Peringkat Obligasi turun 0.549 persen.

5. Koefisien regresi variabel UP bertanda positif $1.567 \mathrm{Hal}$ ini mengindikasikan bahwa variabel UP berhubungan positif dengan Peringkat Obligasi. Jika variabel UP ditingkatkan 1 persen, maka Peringkat Obligasi turun 1.567 persen.

6. Koefisien regresi variabel DK bertanda negatif -0.566 . Hal ini mengindikasikan bahwa variabel DK berhubungan negatif dengan Peringkat Obligasi. Jika variabel DK ditingkatkan 1 persen, maka Peringkat Obligasi turun -0.566 persen.

7. Koefisien regresi variabel PP bertanda positif 0.365 . Hal ini mengindikasikan bahwa variabel PP berhubungan positif dengan Peringkat Obligasi. Jika variabel PP ditingkatkan 1 persen, maka Peringkat Obligasi turun 0.365 persen.

\section{Hasil Uji Hipotesis}

\section{Hasil Uji Hipotesis Pertama}

Nilai signifikansi uji-F variabel X1, X2, X3, X4, X5, X6, X7 sebesar 0,002 lebih kecil dari alpa $5 \%$. Hal ini berarti bahwa secara simultan variabel $X 1, X 2, X 3, X 4, X 5, X 6, X 7$ berpengaruh terhadap Y. dengan demikian, hipotesis pertama yang menyatakan bahwa variabel dewan direksi, kepemilikan manajerial, kepemilikan institusional, komite audit, ukuran perusahaan, dewan komisaris dan profitabilitas perusahaan berpengaruh terhadap peringkat obligasi diterima.

Hasil Uji Hipotesis Kedua

Nilai signifikan uji-t atas variabel X1 sebesar 0,006 lebih kecil dari alpa 0,05. Hal ini berarti bahwa secara parsial variabel X1 berpengaruh terhadap variabel Y. Dengan demikian, hipotesis kedua yang menyatakan bahwa dewan direksi berpengaruh terhadap peringkat obligasi diterima. Hasil Uji Hipotesis Ketiga 
Kunni Fauztina Sahhyla, Pengaruh Mekanisme Good Corporate Governance (GCG) dan Profitabilitas Perusahaan Terhadap Peringkat Obligasi (studi empiris pada Perusahaan Manufaktur yang

terdaftar di BEI tahun 2014-2015)

Nilai signifikan uji-t variabl X2 sebesar 0,135 lebih besar dari alpa 0,05. Hal ini berarti bahwa secara parsial variable X2 tidak berpengaruh terhadap variabel Y. Dengan demikian, hipotesis ketiga yang menyatakan bahwa kepemilikan manajerial berpengaruh terhadap peringkat obligasi tidak diterima atau ditolak.

Hasil Uji Hipotesis Keempat

Nilai signifikan uji-t variabel X3 sebesar 0,183 lebih besar dari alpa 0,05. Hal ini berarti secara parsial variabel X3 tidak berpengaruh terhadap variabel Y. Dengan demikian hipotesis keempat yang menyatakan bahwa kepemilikan institusional berpengaruh terhadap peringkat obligasi tidak diterima atau ditolak.

\section{Hasil Uji Hipotesis Kelima}

Nilai signifikan uji-t variabel X4 sebesar 0,010 lebih kecil dari alpa 0,05. Hal ini berarti bahwa secara parsial variabel $X 4$ bepengaruh terhadap variabel $Y$. Dengan demikian, hipotesis kelima yang menyatakan bahwa variabel komite audit berpengaruh terhadap peringkat obligasi diterima.

Hasil Uji Hipotesis Keenam

Hasil uji hipotesis kelima disajikan pada tabel 4.13 nampak bahwa nilai signifikan uji-t variabel X4 sebesar 0,010 lebih kecil dari alpa 0,05. Hal ini berarti bahwa secara parsial variabel X4 bepengaruh terhadap variabel Y. Dengan demikian, hipotesis kelima yang menyatakan bahwa variabel komite audit berpengaruh terhadap peringkat obligasi diterima.

Hasil Uji Hipotesis Ketujuh

Nilai signifikan uji-t variabel X6 sebesar 0,012 lebih kecil dari alpa 0,05. Hal ini berarti bahwa secara parsial variabel $\mathrm{X} 6$ bepengaruh terhadap variabel Y. Dengan demikian, hipotesis ketujuj yang menyatakan bahwa variabel dewan komisaris berpengaruh terhadap peringkat obligasi diterima.

Hasil Uji Hipotesis Kedelapan

Nilai signifikan uji-t variabel X7 sebesar 0,025 lebih kecil dari alpa 0,05. Hal ini berarti bahwa secara parsial variabel X7 bepengaruh terhadap variabel Y. Dengan demikian, hipotesis kedelapan yang menyatakan bahwa variabel profitabilitas perusahaan berpengaruh terhadap peringkat obligasi diterima.

\section{KESIMPULAN}

Hasil penelitian yang diperoleh dalam penelitian Pengaruh Mekanisme Good Corporate Governance dan Profitabilitas Perusahaan terhadap Peringkat Obligasi adalah sebagai berikut:

1. Mekanisme Good Corporate Governance dan Profitabilitas Perusahaan berpengaruh terhadap Peringkat Obligasi pada Perusahaan Manufaktur yang terdaftar di BEI.

2. Dewan Direksi berpengaruh terhadap Peringkat Obligasi pada Perusahaan Manufaktur yang terdaftar di BEI.Kepemilikan Manajerial tidak berpengaruh terhadap Peringkat Obligasi pada Perusahaan Manufaktur yang terdaftar di BEI.

3. Kepemilikan Institusional tidak berpengaruh terhadap Peringkat Obligasi pada Perusahaan Manufaktur yang terdaftar di BEI.Komite Audit berpengaruh terhadap Peringkat Obligasi pada Perusahaan Manufaktur yang terdaftar di BEI.Ukuran Perusahan berpengaruh terhadap Peringkat Obligasi pada Perusahaan Manufaktur yang terdaftar di BEI.

4. Dewan Komisaris berpengaruh terhadap Peringkat Obligasi pada Perusahaan Manufaktur yang terdaftar di BEI.

5. Profitabilitas Perusahaan berpengaruh terhadap Peringkat Obligasi pada Perusahaan Manufaktur yang terdaftar di BEI.

\section{DAFTAR PUSTAKA}


Kunni Fauztina Sahhyla, Pengaruh Mekanisme Good Corporate Governance (GCG) dan Profitabilitas Perusahaan Terhadap Peringkat Obligasi (studi empiris pada Perusahaan Manufaktur yang terdaftar di BEI tahun 2014-2015)

Abdillah, Selvy Yulita. 2016. Pengaruh Good Corporate Governance terhadap Manajemen Laba. Skripsi. Fakultas Ekonomika dan Bisnis Universitas Kanjuruhan Malang.

Dali, Chandraly, Sautma Roni dan Mariana Ing Malelak. 2015. Pengaruh Mekanisme Good Corporate Governance dan Rasio Keuangan terhadap Peringkat Obligasi. Jurnal Universitas Kristen Petra. FINESTA Vol.3, No.1. diakses 30 Oktober 2016

Dewi, Sofia Prima. 2012. Pengaruh Ukuran Perusahaan, Profitabilitas, Likuiditas, dan Produktifitas terhadap Peringkat Obligasi Perusahaan. Jurnal. Diakses 28 Oktober 2016

Dewi, Kadek Kristiana dan Gerianta Wirawan Yasa. 2016. Pengaruh Good Corporate Governance, Profitabilitas, Likuiditas, dan Solvabilitas terhadap Peringkat Obligasi. E-Jurnal Akuntansi Universitas Udayana. Vol.16.2. Agustus. Diakses 29 Oktober 2016

Ferdinand, Augusty. 2014. Metode Penelitian Mmanajemen. Edisi 5. Seni Pustaka Kunci:Diponegoro.

Fitrianingsih. 2015. Pengaruh Mekanisme Good Corporate Governance terhadap Peringkat Obligasi. Skripsi. Fakultas Ekonomika dan Bisnis Universitas Kanjuruhan Malang.

Ghozali, Imam. 2013. Aplikasi Analisis Multivariate dengan Progam IBM SPSS 19. Edisi Kelima. Universitas Diponegoro. Semarang.

Herianto. 2013. Pengaruh Good Corporate Governance terhadap Kualitas Laba Perusahaan Manufaktur yang terdaftar di Bursa Efek Indonesia. Skripsi. Fakultas Ekonomi dan Bisnis Universitas Hasanudin.

IDX www.idx.co.id

Jelita, Lea Gyna. 2014. Pengaruh Mekanisme Good Corporate Governance Terhadap Peringkat Obligasi. Skripsi. Fakultas Ekonomi Universitas Diponegoro Semarang.

Komite Nasional Kebijakan Governance. 2006. Pedoman Umum GCG Indonesia.

Maria, Delli. 2014. Pengaruh Mekanisme Corporate Governance dan Profitabilitas Perusahaan Terhadap Peringkat Obligasi. Jurnal Ilmiah ESAI. Vol.8, No.2. Fakultas Ilmu Ekonomi dan Bisnis, Progam Studi Akuntansi, Institut Informatika dan Bisnis Darmajaya. Diakses 20 Desember 2016.

Mustikasari, Greta Ika. 2010. Pengaruh Mekanisme Good Corporate Governance terhadap Peringkat Obligasi dan Yield Obligasi. Skripsi. Universitas Sebelas Maret Surakarta. Diakses 30 Oktober 2016

Purwandari. 2011. Pengaruh Mekanisme Good Corporate Governance terhadap Peringkat Obligasi, Jelita, 2014. Skripsi. Fakultas Ekonomi Universitas Diponegoro Semarang.

Rahmayani. 2009. Pengaruh Mekanisme Good Corporate Governance terhadap Peringkat Obligasi, Jelita, 2014. Skripsi. Fakultas Ekonomi Universitas Diponegoro Semarang.

Rasyid, Rosmita dan Ervina Joice Kostaman. 2013. Analisis Pengaruh Good Corporate Governance dan Profitabilitas Perusahaan terhadap Peringkat Obligasi. Jurnal Akuntansi Ukrida.

Rinaningsih. 2008. Pengaruh Praktek Corporate Governance terhadap Resiko Kredit, Yield Surat Hutang (Obligasi). Simposium Nasional Akuntansi XI.

Sugiyono. 2012. Metodologi Penelitian Kuantitatif Kualitatif dan R\&D. Bandung : Alfabetha.

www.pefindo.com 
Kunni Fauztina Sahhyla, Pengaruh Mekanisme Good Corporate Governance (GCG) dan Profitabilitas Perusahaan Terhadap Peringkat Obligasi (studi empiris pada Perusahaan Manufaktur yang terdaftar di BEI tahun 2014-2015)

Yasa, Gerianta Wirawan. 2010. Pemeringkatan Obligasi Perdana sebagai pemicu Manajemen Laba : Bukri Epiris dari Pasar Modal Indonesia. Simposium Nasional Akuntansi XIII. Purwokerto.

Yuliana, Rika, Agus Budiatmo, Muhammad Agung Prabowo, dan Taufik Arifin. 2011. Analisis Faktor-faktor yang Mempengaruhi Prediksi Peringkat Obligasi pada Perusahaan Keuangan yang terdaftar di Bursa Efek Indonesia. Simposium Nasioanal Akuntansi XIV. Aceh.

Yuliana, R., Budiatmo, A., Prabowo, M.A., Arifin, T. 2011. Analisis Faktor-faktor yang Mempengaruhi Prediksi Peringkat Obligasi pada Perusahaan Keuangan yang Terdaftar di BEI. Jurnal SNA XIV Aceh 2011. 